\title{
Seasonal dynamics of phytoplankton communities residing in different types of shallow waters in the Kuibyshev Reservoir (Russia)
}

\author{
L. Yu. Khaliullina $\cdot$ G. V. Demina
}

Received: 9 May 2015/Accepted: 30 September 2015/Published online: 27 October 2015

(C) The Author(s) 2015. This article is published with open access at Springerlink.com

\begin{abstract}
Unstable water level regime in the Kuibyshev Reservoir affects coastline formation as well as allocation and development of aquatic vegetation on the coast. These factors determine the composition and structure of biocenosis in shallow waters of the reservoir. The aim of this study was to reveal the patterns of formation, distribution and dynamics in phytoplankton communities in the shallow coastal waters on two reaches of the Kuibyshev Reservoir (Volga and Volga-Kama, Russia). These reaches differ by the extent of anthropogenic influence, protection from wind and waves and other environmental conditions. The research was done during the growing season of 2002 in the thickets of Typha angustifolia L. and Phragmites australis (Cav.) Trin. Ex Steud., as well as in the open water areas. Seasonal changes in the total biomass and abundance of phytoplankton in the thickets of macrophytes and in the open areas of the reservoir differed little. On the outer edge of the thickets, where intensive contact with the open water occurs, the highest algal species diversity and abundance were revealed, which is known as the "edge effect". Two peaks of phytoplankton development with maximums in June-July and late August were observed. By the end of the summer, a decrease in water level led to the autumn outbreak in volvocine algae abundance and biomass. The maintaining of an optimal water level in the reservoir is recommended for controlling of water "blooming" and thus maintaining high water quality.
\end{abstract}

Keywords Phytoplankton diversity $\cdot$ Phytoplankton dynamics $\cdot$ Algae $\cdot$ Water reservoir - Thickets of macrophytes

\section{Introduction}

The Kuibyshev Reservoir is the sixth stage in the Volga cascade reservoirs, the filling of which took place from 1955 to 1957 after damming the Volga by hydroengineering constructions near the Zhiguli Mountains (Gidrometeorologicheskii rezhim 1978). The total area of the reservoir is $5900 \mathrm{~km}^{2}$. Seasonal water level fluctuations of high amplitude are characteristic to the Kuibyshev Reservoir. The annual water level varies due to significant water inflow and outflow. Spring floods fill the reservoir to maximum levels. Then, for 2-3 months, the level stays close to the normal headwater level of $53 \mathrm{~m}$. By the beginning of the freezing-

\footnotetext{
L. Yu. Khaliullina · G. V. Demina ( $₫)$

Department of Botany and Plant Physiology, Institute of Fundamental Medicine and Biology, Kazan Federal University,

Kremlyovskaya 18, Kazan 420008, Russia

e-mail: deminagv@mail.ru

L. Yu. Khaliullina

e-mail: liliya-kh@yandex.ru
} 
over, the level gradually lowers to $48-49 \mathrm{~m}$, causing significant changes in hydrological and biological parameters of the reservoir, especially in the extensive shallow-water areas (Gidrometeorologicheskii rezhim 1978). At the normal headwater level, shallow waters (not deeper than $2 \mathrm{~m}$ ) occupy $\sim 15 \%$ of the reservoir's total area (Kujbyshevskoe vodohranilishhe 1983, 2008).

The main sources of primary production in shallow waters are macrophytes, coastal phytoplankton and periphyton (Komarkova et al. 1983; Qin et al. 2006; Sayer et al. 2010). The ratio of each structural element in the total vegetation primary production is different depending on the type of the reservoir and may vary significantly throughout the year. The dynamics in the hydrological regime of the reservoir determines the cenotic structure of higher aquatic vegetation (Guseva and Jekzercev 1966; Koreljakova 1977; Kutova 1974a, 1974b; Potapov 1958) and primarily affects the development of planktonic algae communities. Thickets of higher aquatic vegetation are the areas where biocenotic relationships between hydrobionts are more complex than in the pelagic (Gaevskaja 1966; Hilt 2006; Mulderij et al. 2007; Sand-Jensen and Borum 1991; Schriver et al. 1995; Zimbalevskaja 1972, 1973). These relations include not only food networks and toxic effects, but also the roles of plants as substrates or shelters. Phytophilic fauna and algae development in the thickets occur along with the seasonal formation of plant biotopes.

The area of overgrown shallow waters in the Kuibyshev Reservoir is 8500 ha, with the most extensive areas in the Volga and the Volga-Kama reaches. The phytoplankton communities in the Volga cascade artificial water reservoirs are crucial for reservoirs' ecosystems, in particular for the trophic status and biological productivity of the reservoir (Khaliullina et al. 2009; Konovalov and Pautova 1989; Lavrent'eva 1977; Okhapkin 1994; Pautova and Nomokonova 1994, 2001). Since the 1970s, long-term monitoring of seasonal phytoplankton dynamics in the Kuibyshev water reservoir has been carried out (Gidrometeorologicheskii rezhim 1978; Khaliullina et al. 2009; Konovalov and Pautova 1989; Pautova and Nomokonova 1994). However, some open questions still remain. In particular, the mechanisms of phytoplankton succession in the reservoirs are not well understood. Here, we provide more insights into the patterns of formation, distribution and dynamics of phytoplankton in the coastal shallows in the two reaches of the Kuibyshev Reservoir. The comparison of phytoplankton dynamics in these sites is of special interest, as the sites differ in the extent of anthropogenic impact, the degree of protection from wind and waves and other environmental conditions. Samples collected from both macrophytes thickets and areas of open water were analyzed for the phytoplankton abundance and biomass.

\section{Materials and methods}

Water samples were taken from two shallow bays of the Volga (site 1) and the Volga-Kama (site 2) reaches of the Kuibyshev Reservoir (Russian Federation, Republic of Tatarstan) (Fig. 1) in 2002.

Site 1 is located in Pobedilovo township (southern part of Kazan city) and is substantially isolated from the other parts of the reservoir. In the studied area, the water flow is slow, and the bank is protected from wind.

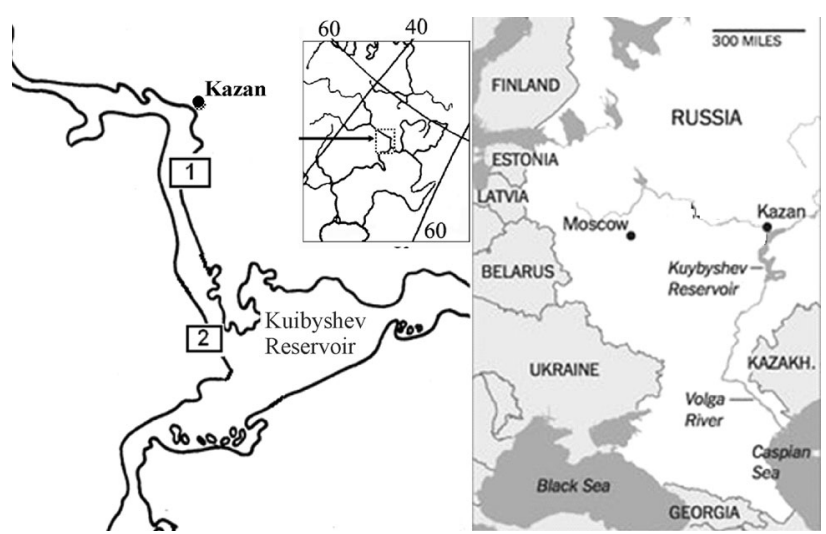

Fig. 1 Layout of the studied coastal shallow water areas in the Volga and the Volga-Kama reaches of the Kuibyshev Reservoir: site 1 (1) (Pobedilovo, Kazan) and site 2 (2) (Saralinsky, Volga-Kama State Nature Biosphere Reserve) (Khaliullina 2015) 
The site is influenced by waste waters produced by sewage disposal plants and suburban areas. The right bank of the bay, where the observing stations were located, is low-laying, overgrown with single willow bushes and riverside vegetation. The bottom is flat and covered with sticky mud. Next to willow thickets, higher aquatic vegetation is represented mainly by thickets of narrow-leaved cat's-tail (Typha angustifolia L.) and common reed [Phragmites australis (Cav.) Trin. Ex Steud.]. In July, the general projective covering by plants reaches $100 \%, 50 \%$ of which are narrow-leaved cat's-tail and common reed, and the other $50 \%$ are free-swimming plants (Spirodela sp., Lemna minor L., L. trisulca L.). At the end of August, the ratio becomes 90 and $10 \%$, respectively. In the thickets area, argillaceous sand grounds with high content of organic residues dominate. This area is characterized by a relatively high trophic status. In the open shallow water, sludgy argillaceous sand grounds also dominate.

Site 2 is located near the settlement Tatar Sarali (Laishevski district) and is a part of Saralinsky section of the Volga-Kama State Nature Biosphere Reserve. In site 2, along with seasonal fluctuations in water level, the impact of transit water flows (generally characteristic for this water area of the reservoir) is significant. This site is characterized by slightly irregular coastline, and is located in the zone of high wind and wave activity. The sampling stations were located on the peninsula, the coastal zone of which is covered with willow beds and thickets of narrow-leaved cat's-tail. The latter ones extend along the coastline as continuous zones ( $\sim 60 \mathrm{~m}$ wide) with small clearings of open littoral. Their projective cover is $100 \%$. In mid-summer, the dominant narrow-leaved cat's-tail occupies $\sim 60 \%$ of the territory, and 30-40\% is occupied by Spirodela sp. and Lemna minor L. In coastal thickets, the bottom is covered mainly with sandy-mud and argillo-arenaceous grounds. Large amounts of decaying plant residues are accumulating in the bottom, which leads to siltation and oxygen deficiency in the thickets. In shallow waters of open areas, slightly muddy argillo-arenaceous grounds dominate. Below the area of thickets, open littoral is represented by fine brown (homogeneous) clayey silts.

The studied areas of both sites included the thickets of narrow-leaved cat's-tail and common reed, as well as open water areas. Water samples were taken from three stations with different water levels: from the top of macrophyte thickets to the deepest water level in the bottom of the thickets (Fig. 2). For comparison, we laid three control points in the areas free of vegetation at the same water levels.

At each site, the studies were carried out starting from the time of flooding in the shallow waters with higher aquatic vegetation (June) until the time of drainage (mid-October). The samples were taken once every 2 weeks. In total, more than 240 quantitative and over 300 qualitative samples of phytoplankton were handled. During the study period, weather conditions and hydrological characteristics of the reservoir were recorded.
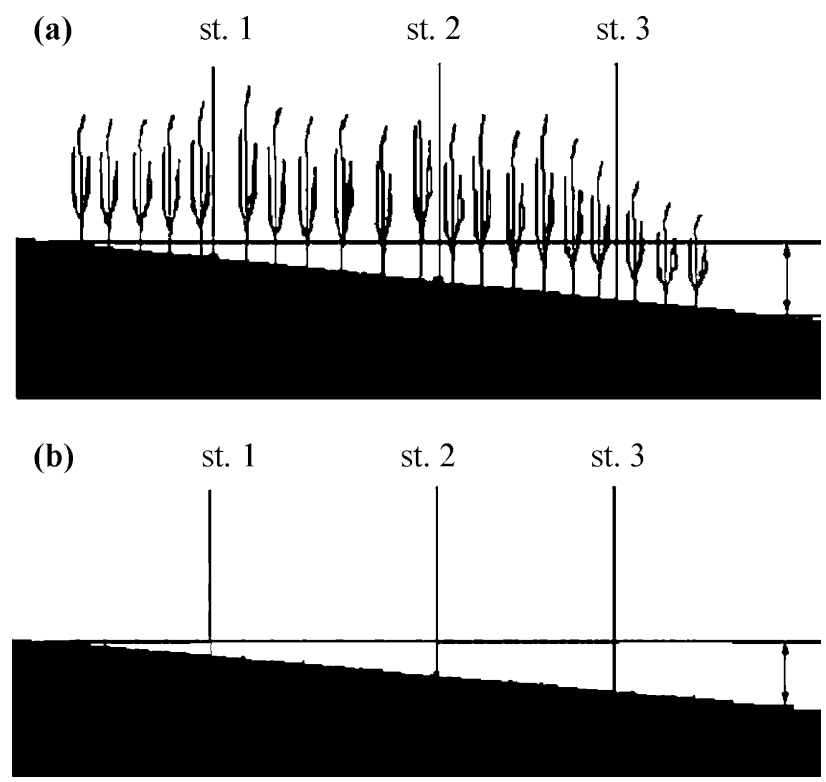

Fig. 2 The schematic location of the stations in the thickets (a) and in the open shallow waters (b) of two sites in the Volga and the Volga-Kama reaches shown as cross-sections. Station 1 (st. 1) was located near the bank, at the water depth of $0.5-0.7 \mathrm{~m}$, station 2 (st. 2) at $0.7-1.0 \mathrm{~m}$, and station 3 (st. 3) at 1.0-1.2 m. Arrows indicate the amplitude of seasonal water level fluctuations 
The sampling and laboratory processing of phytoplankton samples was performed according to conventional methods (Vodorosli spravochnik 1989; Morduhaj-Boltovskoj 1975). The samples were taken with Molchanov bathometer. All quantitative samples $(0.5 \mathrm{l})$ were fixed with $4 \%(\mathrm{v} / \mathrm{v})$ formalin. Qualitative samples were taken with Apshtein small network (mill sieve No. 73) by filtering 50-100 1 of water. The fixed samples were concentrated to 20-30 ml. The present organisms were counted in hemocytometer. For each algae species, the individual cell size was calculated by stereometric method. To determine the biomass, the counting-volumetric method was used. In each sample, an average volume of cells was determined for each algae species (not less than 20 cells inspected). For rare organisms, their individual volumes were used, measured in every sample. Statistical data processing was performed using parametric ( $t$ test, mean and its standard error) and non-parametric tests (Wilcoxon test, Spearman rank correlation) (Borovikov and Borovikov 1998).

\section{Results and discussion}

Hydrochemical regime of the studied sites

According to the data provided by the hydrochemistry laboratory of the Institute of Natural Systems Ecology (Tatarstan Academy of Sciences), as well as our own data, it was found that site 1 belongs to the $\alpha$ -

Table 1 Average hydrochemical parameters of the studied sites of shallow waters in the Kuibyshev Reservoir in 2002-2003, adapted from Ratushnyak et al. (2006a, b)

\begin{tabular}{|c|c|c|c|c|c|c|}
\hline \multirow[t]{2}{*}{ Parameter } & \multicolumn{3}{|l|}{ Site 1} & \multicolumn{3}{|l|}{ Site 2} \\
\hline & $\mathrm{M} \pm \mathrm{SE}$ & Min. & Max. & $\mathrm{M} \pm \mathrm{SE}$ & Min. & Max. \\
\hline $\mathrm{O}_{2}(\mathrm{mg} / \mathrm{l})$ & $10.7 \pm 0.9$ & 2.2 & 19.6 & $7.6 \pm 0.8$ & 0.4 & 16.3 \\
\hline $\mathrm{Eh}(\mathrm{mV})$ & $148.5 \pm 10.2$ & 57.0 & 223.0 & $130.4 \pm 21.4$ & 201.0 & 313.0 \\
\hline $\mathrm{pH}$ & $7.3 \pm 0.1$ & 6.0 & 8.7 & $7.2 \pm 0.1$ & 6.4 & 9.1 \\
\hline$\Sigma \min .(\mathrm{mg} / \mathrm{l})$ & $468.2 \pm 15.9$ & 307.6 & 854.0 & $248.6 \pm 6.2$ & 171.0 & 414.9 \\
\hline $\mathrm{Ca}^{2+}(\mathrm{mg} / \mathrm{l})$ & $84.7 \pm 3.9$ & 40.0 & 178.0 & $44.1 \pm 1.4$ & 20.8 & 96.0 \\
\hline $\mathrm{Mg}^{2+}(\mathrm{mg} / \mathrm{l})$ & $20.1 \pm 1.7$ & 1.8 & 40.9 & $9.3 \pm 0.7$ & 1.2 & 29.2 \\
\hline $\mathrm{HCO}_{3}^{-}(\mathrm{mg} / \mathrm{l})$ & $170.6 \pm 3.8$ & 122.0 & 263.6 & $136.8 \pm 3.5$ & 110.0 & 276.1 \\
\hline $\mathrm{SO}_{4}^{2-}(\mathrm{mg} / \mathrm{l})$ & $165.4 \pm 8.3$ & 21.0 & 377.0 & $54.3 \pm 2.6$ & 15.8 & 99.9 \\
\hline $\mathrm{Cl}^{-}(\mathrm{mg} / \mathrm{l})$ & $39.9 \pm 1.2$ & 24.8 & 59.6 & $22.7 \pm 0.9$ & 15.6 & 46.8 \\
\hline $\mathrm{BO}\left(\mathrm{mg} \mathrm{O}_{2} / \mathrm{l}\right)$ & $33.9 \pm 2.6$ & 14.3 & 92.8 & $24.0 \pm 2.3$ & 3.1 & 78.0 \\
\hline $\mathrm{PO}\left(\mathrm{mg} \mathrm{O}_{2} / \mathrm{l}\right)$ & $12.2 \pm 0.9$ & 1.7 & 28.8 & $11.5 \pm 0.5$ & 6.7 & 20.4 \\
\hline $\mathrm{BOD}_{5}\left(\mathrm{mg} \mathrm{O}_{2} / \mathrm{l}\right)$ & $5.9 \pm 0.6$ & 0.9 & 11.5 & $4.8 \pm 0.8$ & 0.5 & 18.6 \\
\hline$P_{\text {total }}(\mathrm{mg} / \mathrm{l})$ & $0.28 \pm 0.03$ & 0.07 & 0.59 & $0.29 \pm 0.04$ & 0.05 & 0.74 \\
\hline $\mathrm{PO}_{4}{ }^{3-}(\mathrm{mg} / \mathrm{l})$ & $0.09 \pm 0.01$ & 0.003 & 0.46 & $0.10 \pm 0.02$ & 0.001 & 0.80 \\
\hline $\mathrm{NO}_{3}^{-}(\mathrm{mg} / \mathrm{l})$ & $1.88 \pm 0.22$ & 0.10 & 7.86 & $1.15 \pm 0.11$ & 0.11 & 3.60 \\
\hline $\mathrm{NO}_{2}{ }^{-}(\mathrm{mg} / \mathrm{l})$ & $0.09 \pm 0.02$ & 0.003 & 0.69 & $0.07 \pm 0.02$ & 0.001 & 1.25 \\
\hline $\mathrm{NH}_{4}{ }^{+}(\mathrm{mg} / \mathrm{l})$ & $0.67 \pm 0.10$ & 0.02 & 5.34 & $0.49 \pm 0.04$ & 0.02 & 1.48 \\
\hline $\mathrm{Cd}(\mu \mathrm{g} / \mathrm{l})$ & $1.15 \pm 0.27$ & 0.01 & 7.50 & $1.0 \pm 0.2$ & 0.1 & 4.6 \\
\hline $\mathrm{Pb}(\mu \mathrm{g} / \mathrm{l})$ & $11.6 \pm 2.1$ & 0.1 & 48.0 & $9.3 \pm 1.6$ & 0.2 & 31.5 \\
\hline $\mathrm{Cu}(\mu \mathrm{g} / \mathrm{l})$ & $6.4 \pm 0.7$ & 0.5 & 29.5 & $5.8 \pm 0.5$ & 0.5 & 16.1 \\
\hline Co $(\mu \mathrm{g} / \mathrm{l})$ & $7.9 \pm 0.6$ & 0.7 & 14.3 & $6.3 \pm 0.5$ & 0.9 & 14.2 \\
\hline $\mathrm{Ni}(\mu \mathrm{g} / \mathrm{l})$ & $12.5 \pm 0.9$ & 1.0 & 19.7 & $10.8 \pm 0.8$ & 0.5 & 19.9 \\
\hline $\mathrm{Zn}(\mu \mathrm{g} / \mathrm{l})$ & $17.8 \pm 1.7$ & 1.1 & 42.6 & $17.9 \pm 2.5$ & 0.9 & 67.1 \\
\hline $\mathrm{Cr}(\mu \mathrm{g} / \mathrm{l})$ & $4.9 \pm 0.7$ & 1.5 & 9.5 & $3.4 \pm 0.5$ & 1.7 & 8.1 \\
\hline $\operatorname{Mn}(\mu \mathrm{g} / \mathrm{l})$ & $89.4 \pm 29.3$ & 3.5 & 1198.0 & $114.6 \pm 35.7$ & 6.0 & 1176.0 \\
\hline $\mathrm{Fe}(\mu \mathrm{g} / \mathrm{l})$ & $239.0 \pm 47.4$ & 1.0 & 1344.0 & $209.5 \pm 42.7$ & 22.5 & 1555.0 \\
\hline
\end{tabular}

$M$ mean, $S E$ standard error, Min. the minimal value, Max. the maximum value, Smin. total mineralization, $B O$ bichromate oxidizability, $\mathrm{PO}$ permanganate oxidizability, $\mathrm{BOD}_{5}$ biological oxygen demand for 5 days 


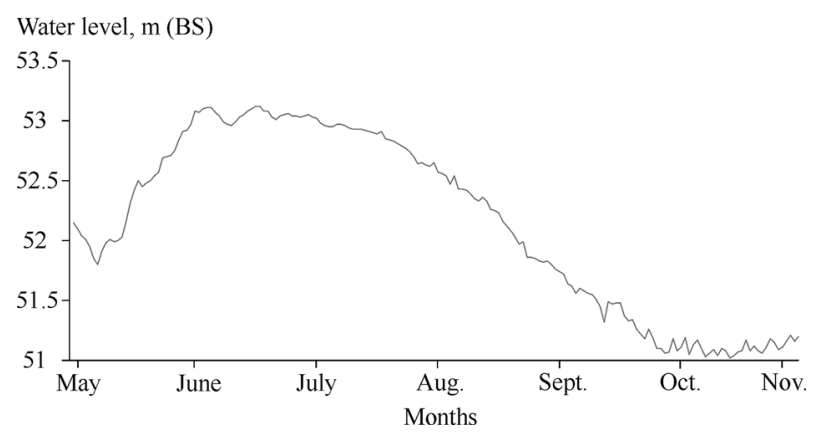

Fig. 3 Seasonal dynamics of the water level in the Kuibyshev Reservoir in 2002. (Kujbyshevskoe vodohranilishhe 2008). Water level is in Baltic system (BS)

mesosaprobic zone, 3-4 class of water quality, and is assessed as "polluted". Site 2 belongs to $\beta$-mesosaprobic zone, 3 class of water quality and is characterized as "of satisfactory purity" (Kazda et al. 2004; Ratushnyak et al. 2006a, b). The studied shallow water sites were significantly different in chemical composition. Integrated assessment of water quality in sites 1 and 2 based on the average ranking index is shown in Table 1 .

Identified excess of mineral content, organic and biogenic elements in site 1 compared to site 2 is explained by the inflow of contaminated industrial and domestic wastewaters from Kazan sewage disposal plants, located upstream. Their typical ingredients are sulfates, chlorides, and heavy metals (Stepanova 1999).The concentration of dissolved oxygen in the two studied sites is characterized by a negative correlation with the content of organic compounds. The oxygen concentration at site 1 remained consistently higher than that at the cleaner site 2. Significant correlations between the oxygen, organic matter contents $\left(\mathrm{BO}, \mathrm{ON}, \mathrm{BOD}_{5}\right)$, and phytoplankton indicators in the surface layers have not been identified. Probably, the reason for such distribution is to be found in production-destruction features of these sites.

Seasonal dynamics of water level and weather conditions in 2002

In 2002, the water level rose constantly starting with the spring filling of the reservoir until June 5 when it reached $53.11 \mathrm{~m}$ in the Baltic System (BS) and stayed at this level with small fluctuations caused by winddriven waves until the June 17 (Kujbyshevskoe vodohranilishhe 2008). Later, the water level gradually decreased, and in September-October, it was 51.02 m (Fig. 3).

May 2002 was cold and rainy. Monthly rainfall exceeded the norm by $18 \mathrm{~mm}$ (Gosudarstvennyj doklad 2003, 2005). Monthly average temperatures were $3-4{ }^{\circ} \mathrm{C}$ lower than long-term averages. At the soil surface frosts were recorded $\left(-3\right.$ to $\left.-11^{\circ} \mathrm{C}\right)$. Especially cold weather was observed in the third decade of May. The average air temperature of the decade was the lowest for the observation period since 1924. In the northern regions of Tatarstan Republic the snowfalls were registered on May 21, and in some areas, the formation of a temporary snow cover was observed. The average monthly temperature in June was $1-2{ }^{\circ} \mathrm{C}$ lower than the long-term average. Monthly rainfall exceeded the long-term "norm", except for the most part of Predvolzhje, where the rainfall of only $28-70 \%$ of the "norm" was registered. In July, average temperatures exceeded the long-term average by $2-4{ }^{\circ} \mathrm{C}$, and the weather was hot and dry. In August, cool weather (average temperature of $2-3{ }^{\circ} \mathrm{C}$ below the norm) with a deficit of rainfall was observed. September and October were characterized by unstable weather and significant variations in temperature (in the first decade of September, the maximum air temperature rose to $25-29{ }^{\circ} \mathrm{C}$ ). The average monthly air temperature was $1-2{ }^{\circ} \mathrm{C}$ above the norm. Precipitation in October amounted to $1-2$ norms.

Seasonal changes in phytoplankton species diversity at different biotopes in 2002

During the observation period, 336 taxa, including 323 species of algae belonging to eight divisions, were found in phytoplankton of the studied sites. The greatest number of order-level taxa was identified in the divisions of chlorophytes and diatoms. In species-level diversity diatoms (26.2\%) and Chlorococcales $(36.8 \%)$ also dominated. Other groups were less diverse: cyanobacteria $(12.1 \%)$, euglenophytes $(7.8 \%)$, chrysophytes $(6.9 \%)$, xanthophytes $(4.4 \%)$, dinoflagellates $(3.7 \%)$, and cryptophytes $(2.2 \%)$. 
At the beginning of the growing season, phytoplankton of both sites differed little in composition and was represented by diatoms. In mid-summer, when the thickets of cat's-tail and reed were grown, a complex of phytoplankton algae formed at the station 2 was different from that formed in the open shallow water, which was particularly noticeable at site 1 (Pobedilovo). This algocoenosis included several ecological groups of algae (true phytoplankton, epipelon, epiphyton, free-floating strands and clumps of filamentous algae), which differed in species composition, habitat conditions and development dynamics. In the species diversity diatoms, cyanobacteria, Desmidiales, and euglenophytes dominated.

The highest algae abundance and species diversity was typical for station 3 (at the outer edge of the thickets at both sites), where an intensive contact with open water occurred $(p<0.05)$. The border area between algae communities of thickets and the open pelagic zone of the reservoir is a sort of ecotone. For such zones an "edge effect" is known, i.e. there is an increase in biodiversity and abundance in the mixing zone (Harchenko

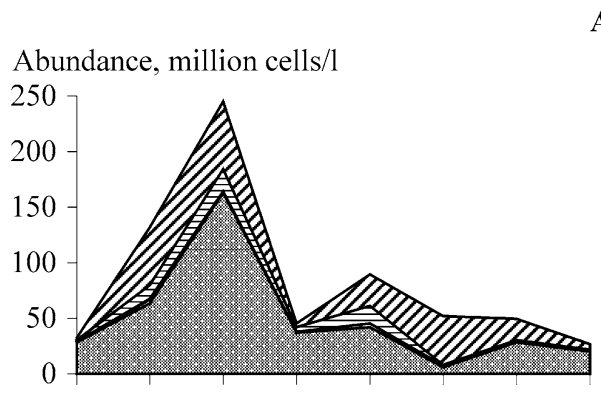

A

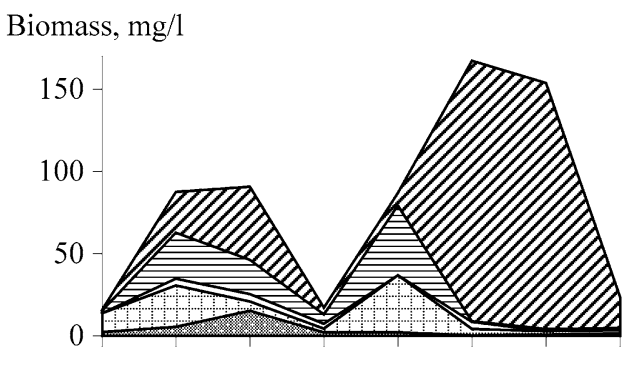

B
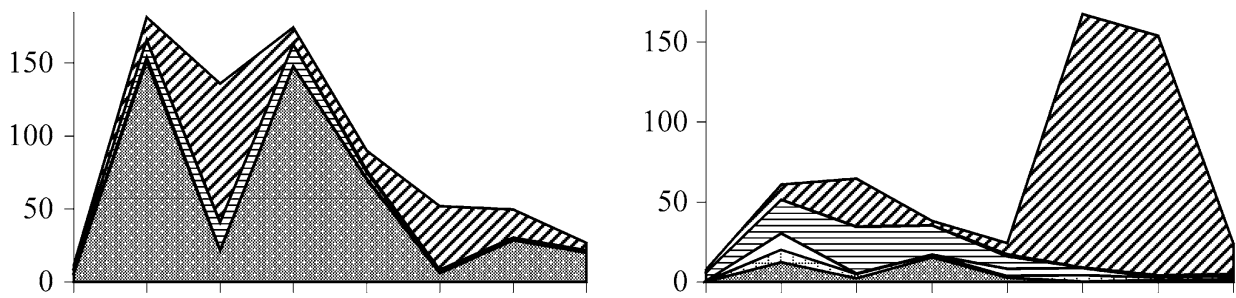

C
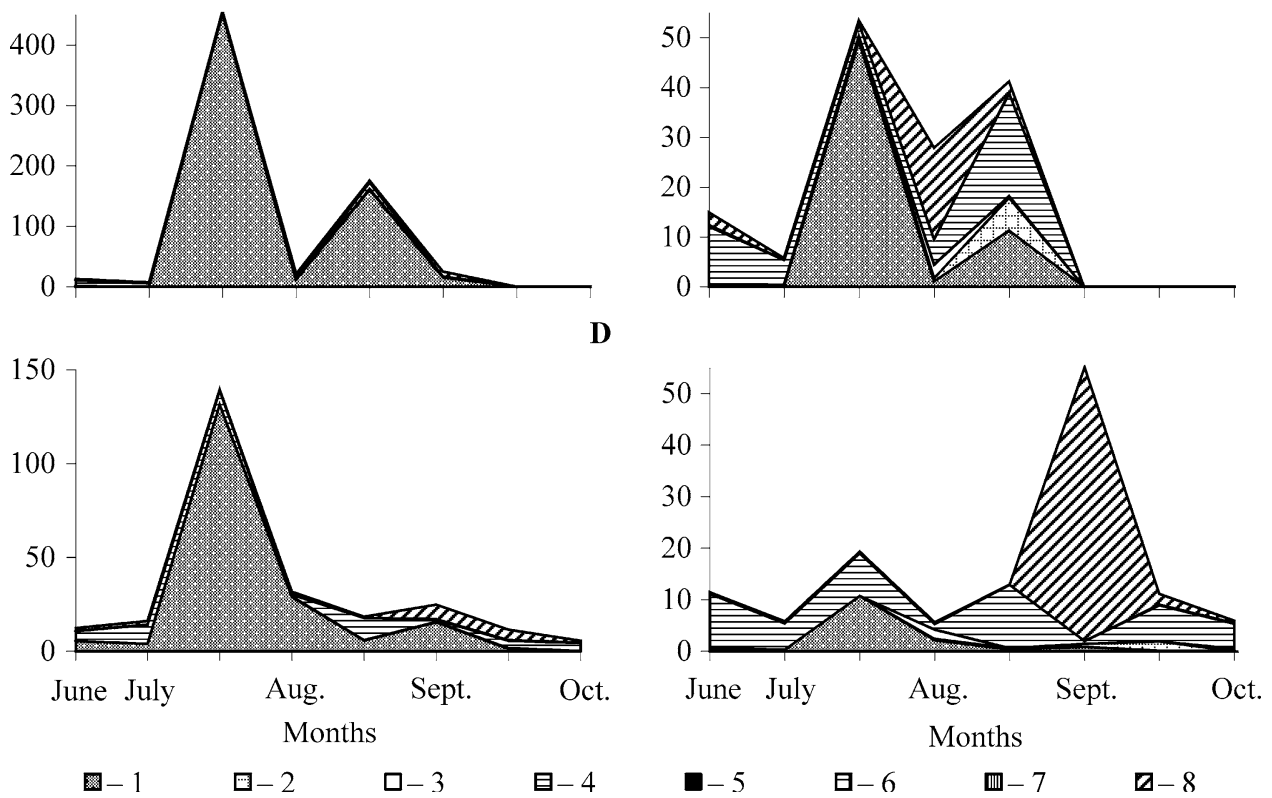

Fig. 4 Dynamics of phytoplankton total abundance and biomass at different biotopes of site $1(\mathbf{a}, \mathbf{b})$ and site 2 (c, d) in cats'-tail thickets (a, c), common reed thickets (b), open shallow water (d). Cyanobacteria (1), euglenophytes (2), dinoflagellates (3), diatoms (4), xanthophytes (5), cryptophytes (6), chrysophytes (7), chlorophytes (8) 
1991; Solov'eva and Rozenberg 2006). The effect was observed in both studied sites. Under the conditions of mixing with water masses coming from the open pelagic, the role of true phytoplankton significantly increased. Here, the above-mentioned groups of station 2 were joined by algae washed to the thickets by wind, as these algae can grow only in the open waters of reservoirs and under conditions of wind-mixing water (Vodorosli. lishajniki 1977). Epiphytic species of diatoms and chlorophytes at station 3 maintained a high abundance and species diversity throughout the whole growing season, withstanding even strong shading by macrophytes starting from mid-summer. No significant differences in species composition of phytoplankton communities in cat's-tail and reed thickets were observed during the study period. In open shallow water, phytoplankton was distributed evenly and consisted mainly of truly planktonic species and less of epipelon species.

Thus, the floristic list of phytoplankton in shallow coastal water of the reservoir is "saturated" during the entire growing season. The total number of recorded algae taxa approaches the maximum during the summerautumn period. The "saturation" of the diatoms list occurs already in early summer, while the list of chlorophytes is constantly increasing by the beginning of autumn. The highest species diversity is observed in genera Aulacoseira, Navicula, Nitzschia, and Scenedesmus. In formed algocoenoses, relatively large-cell species dominate during spring, and species with small-sized cells are more prevalent during the summer. The observed decrease in the average quantities of diatoms and chlorophytes along the formation of biocenosis in shallow water zone and during the summer seems to be the result of competitive relationships between algae. At the same time, the advantage is given to rapidly proliferating algae with larger relative cell surface.

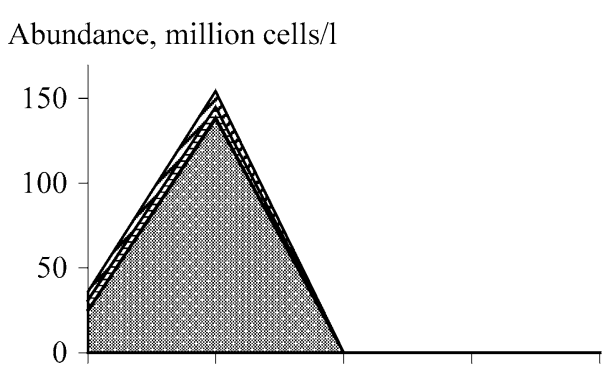

A

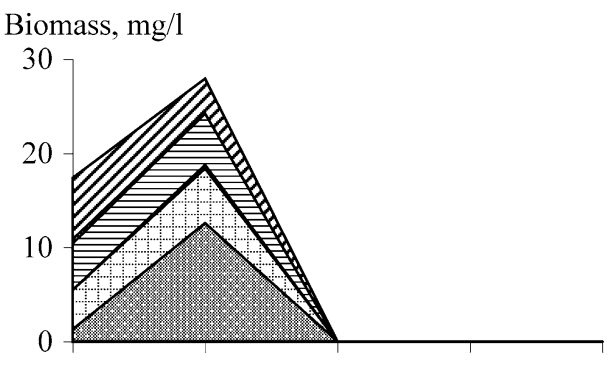

B
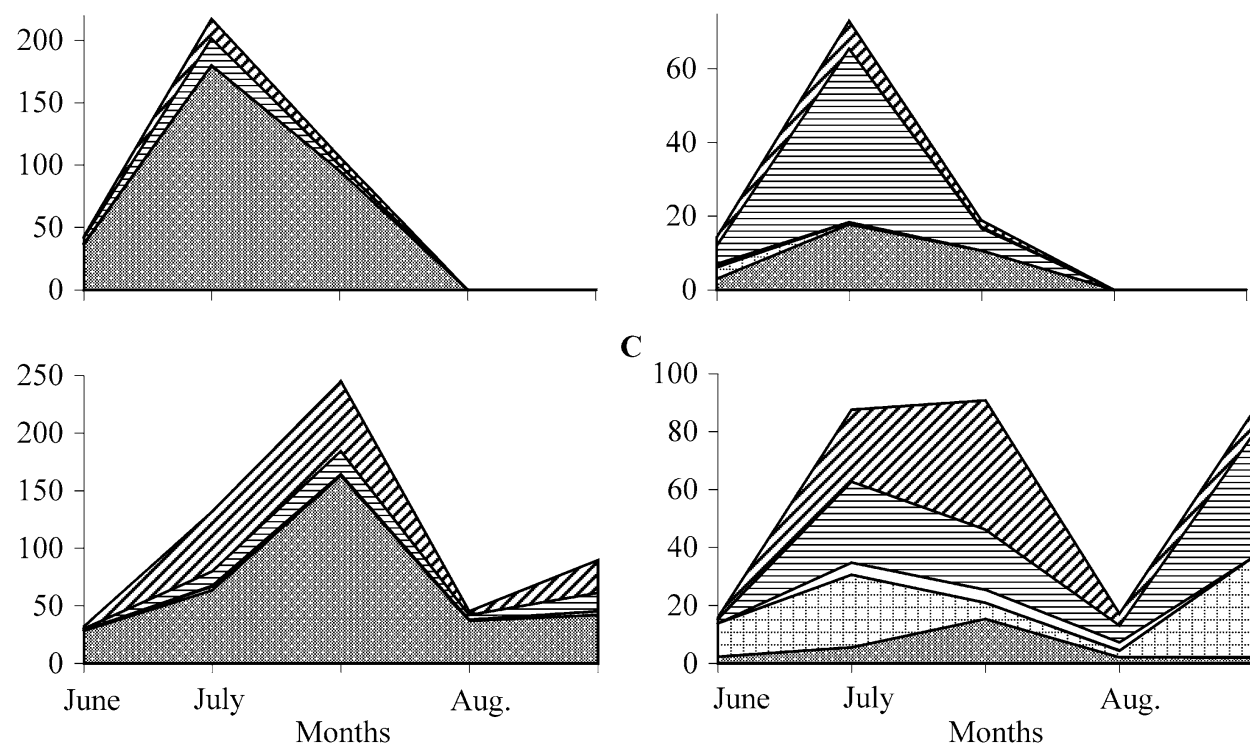

C
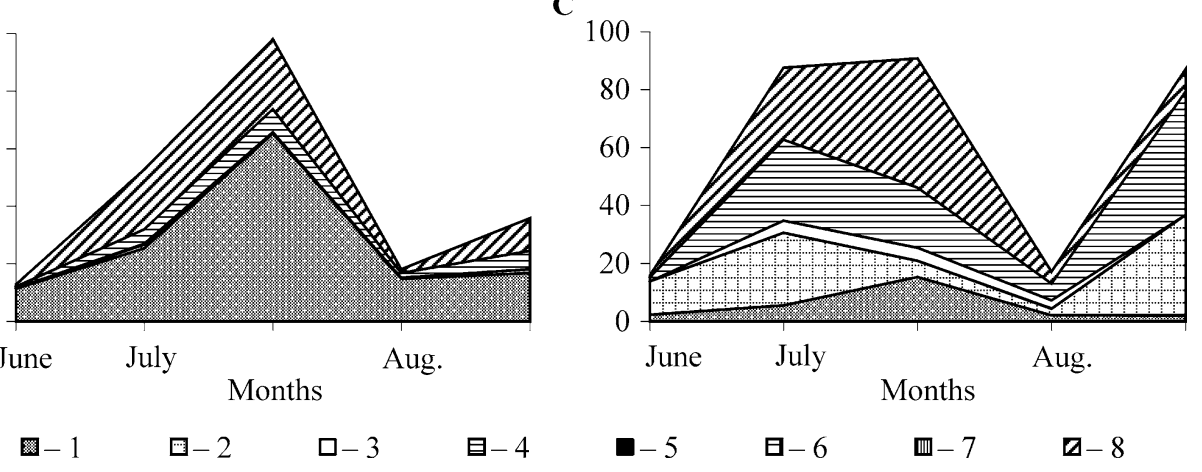

Fig. 5 Seasonal dynamics of phytoplankton abundance and biomass in cats'-tail thickets at station 1 (a), station 2 (b), and station 3 (c) of site 1 (Pobedilovo). Cyanobacteria (1), euglenophytes (2), dinoflagellates (3), diatoms (4), xanthophytes (5), cryptophytes (6), chrysophytes (7), chlorophytes (8) 
Seasonal changes in phytoplankton abundance and biomass at different biotopes in 2002

During the period of maximal water level (in the first half of summer), higher aquatic vegetation was poorly developed, and algocoenoses associated with thickets had not been formed yet. The water in the reservoir was homogeneous, and the quantitative parameters of phytoplankton in macrophytes thickets and in open shallow water differed slightly. In this period, the total abundance and biomass of phytoplankton at both sites were low and were associated mainly with the development of cyanobacteria, diatoms, and volvocine algae (Fig. 4).

At both sites, all the biotopes were dominated by cyanobacteria Aphanizomenon flos-aquae (1.) Ralfs. (up to $1.99 \times 10^{8}$ cells/l), Anabaena flos-aquae Breb., Anabaena scheremetievi Elenc., diatoms Stephanodiscus hantzschii Crun., genera Aulacoseira, Melosira, Cyclotella, Nitzschia, dinoflagellates of genus Peridinium, chlorophytes of genus Chlamydomonas. In associations with narrow-leaved cats'-tail and common reed, the dominant complex also included euglenophytes of genera Euglena and Trachelomonas. The highest biomass of these algae was observed at site 1 . Spearman correlation analysis revealed a negative relationship between the abundance of this group and water clarity $(p<0.01)$. Quantitative parameters of phytoplankton in the thickets of cats'-tail and reed differed little.

In macrophytes thickets at site 1 (Pobedilovo), the number of chlorophytes was higher in the areas closer to the open water $(p<0.03)$. The distribution of other algae other groups at three stations was even, and no significant differences between the coastal zone (station 1) and the outer edge of the thickets (station 3 ) were observed (Figs. 5, 6).
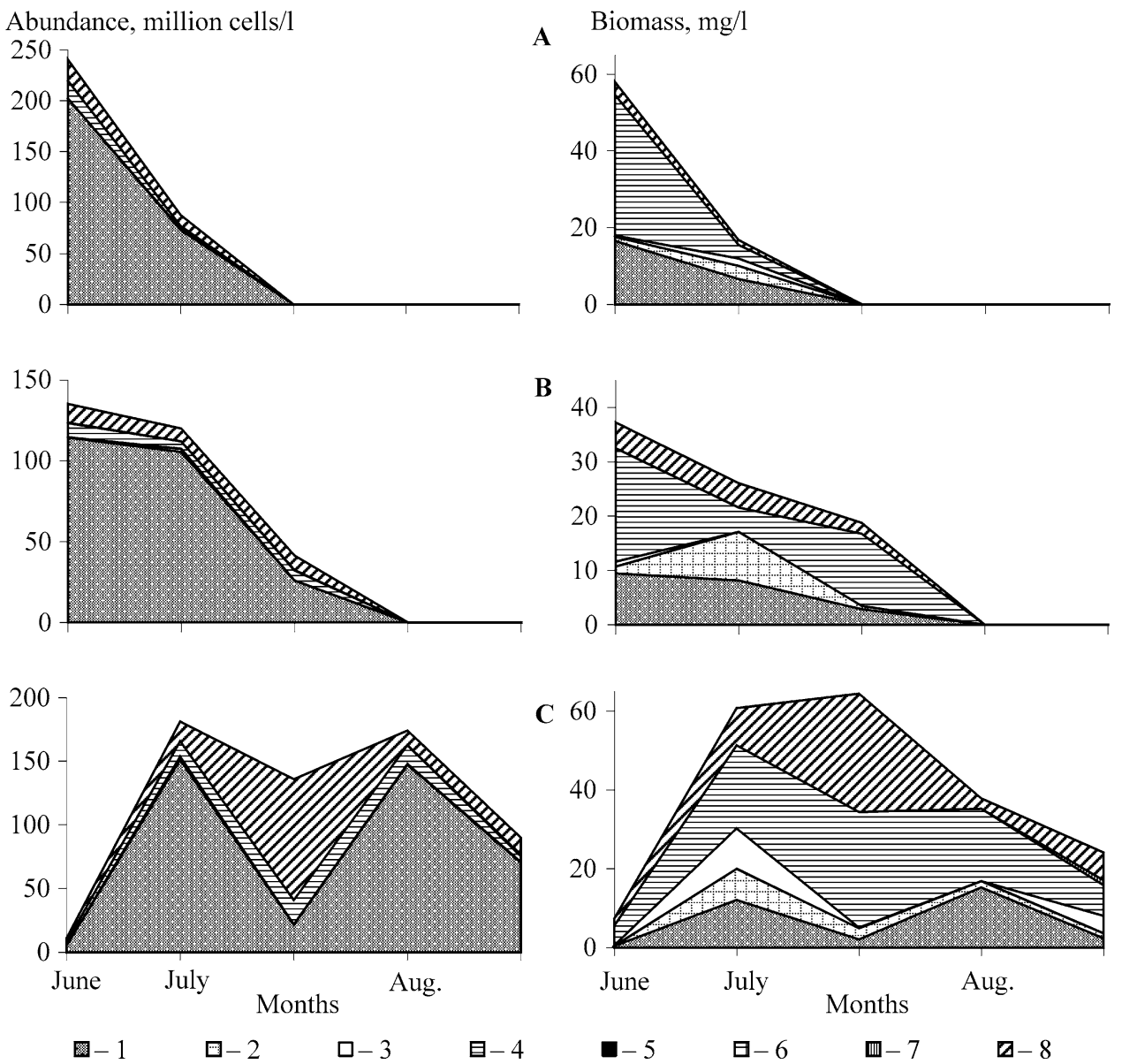

Fig. 6 Seasonal dynamics of phytoplankton abundance and biomass in common reed thickets at station 1 (a), station 2 (b), and station 3 (c) of site 1 (Pobedilovo). Cyanobacteria (1), euglenophytes (2), dinoflagellates (3), diatoms (4), xanthophytes (5), cryptophytes (6), chrysophytes (7), chlorophytes (8) 
At site 2 (Saralinsky), in cats'-tail thickets, the abundance of diatoms increased closer to the coast (Figs. 7, 8). At the stations located close to the water's edge and rich with detritus (stations 1, 2), high biomass of periphyton and benthic-planktonic diatoms with large cells and low abundance was noticed. These algae included Nitzschia sigmoidea (Nitzsch.) W.Sm., N. vermicularis (Kiitz.) Grun., Gyrosigma acuminatum (Kiitz.) Rabenh., Cymatopleura elliptica (Breb.) W.Cm., C. solea (Breb.)W.Sm., Cymbella sp. In the open shallow water, no differences in phytoplankton were detected at the stations.

In May-June 2002, large fluctuations in water level were observed. After that, the water level was gradually decreasing, which led to the drying up of some shallow coastal waters. Moderate dynamics of water masses and high warming up of the water due to hot and dry weather led to intensive development of phytoplankton. During this period, the spring algocoenosis was completely replaced by the summer one. By that time, stations 1 of all studied biotopes almost remained above the water's edge.

The first maximum in phytoplankton abundance and biomass in the thickets and open shallow water was observed in mid-July. Green-blue algae A. flos-aquae, An. flos-aquae, An. scheremetiev, Microcystis aeruginosa f. flos-aquae (Wittr.) Elenk. were the most abundant, causing water "blooming". Moreover, their high abundance was observed at all stations of both sites, except for stations 1 and 2 in the open shallow water of site 2, where diatoms dominated. In addition, by that time, the abundance of chlorophytes and euglenophytes had increased at site 1 (Pobedilovo).

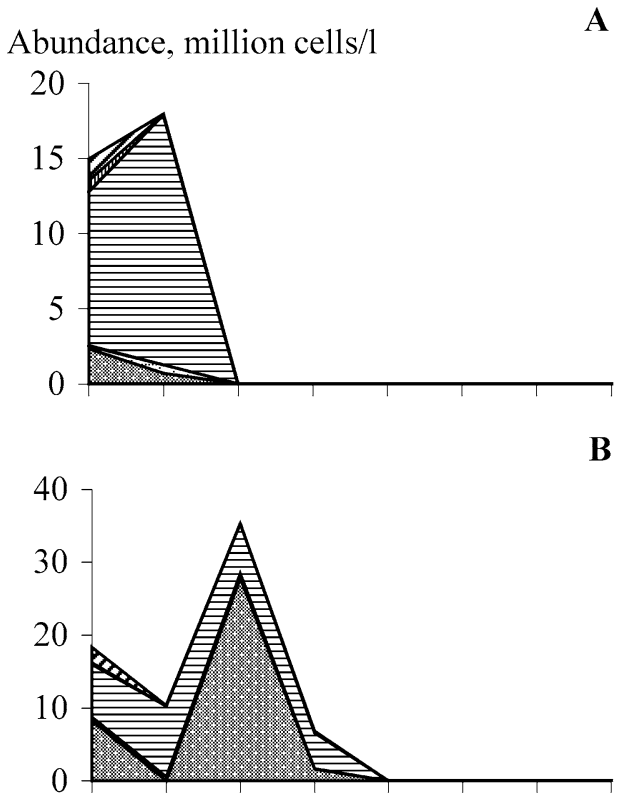

A

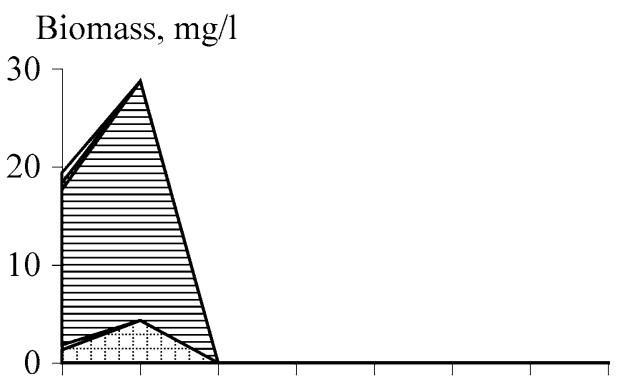

B
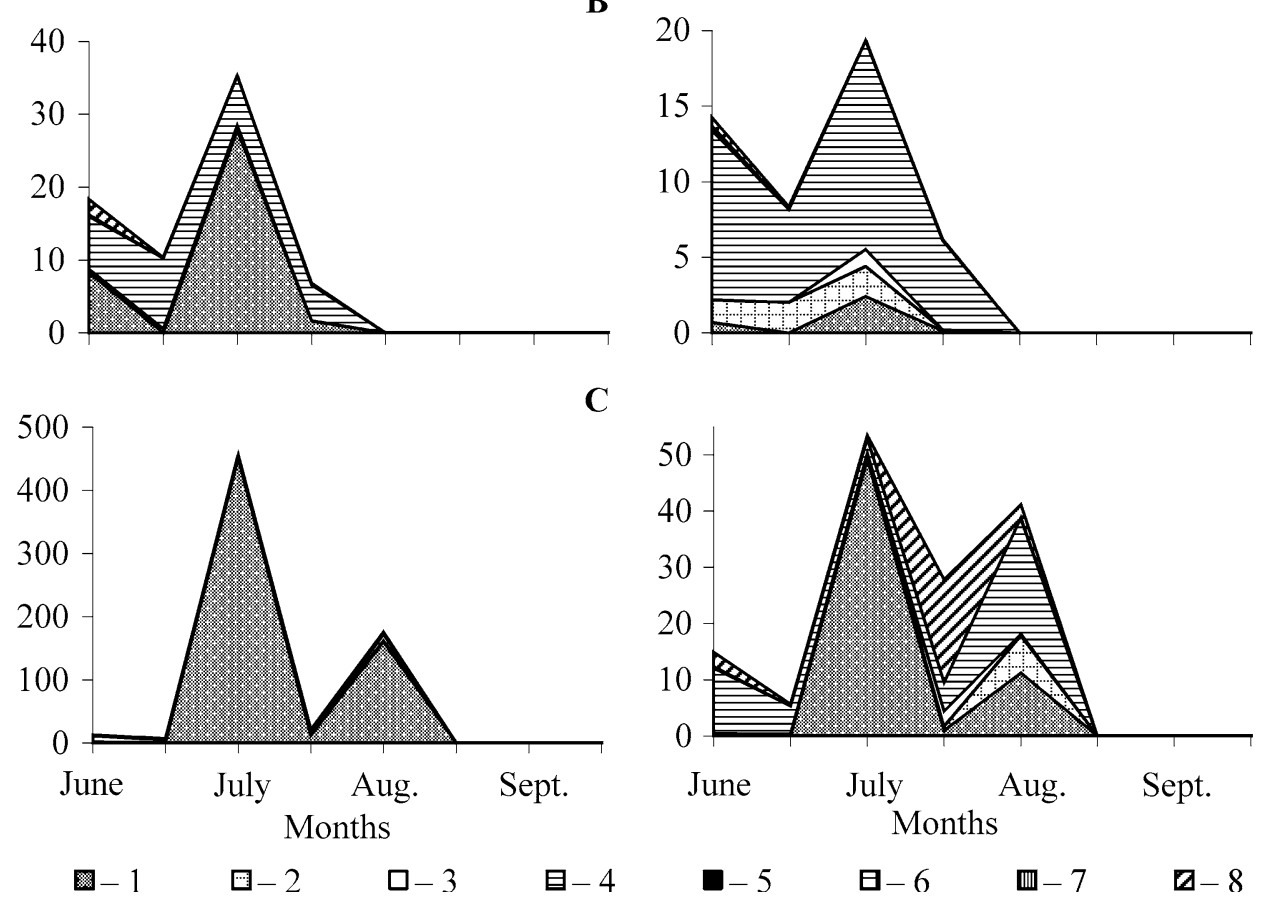

C

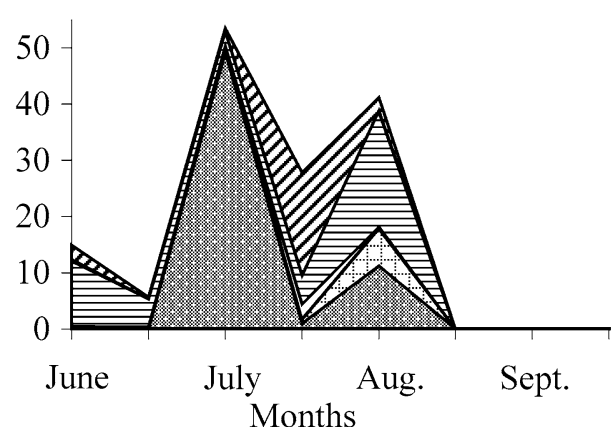
- 1
$\square-2$
$\square-3$
目 -4

$\square-5$

日- 6

四 -7 口

Fig. 7 Seasonal dynamics of phytoplankton abundance and biomass in cats'-tail thickets at station 1 (a), station 2 (b), and station 3 (c) of site 2 (Saralinsky). Cyanobacteria (1), euglenophytes (2), dinoflagellates (3), diatoms (4), xanthophytes (5), cryptophytes (6), chrysophytes (7), chlorophytes (8) 
Abundance, million cells/1
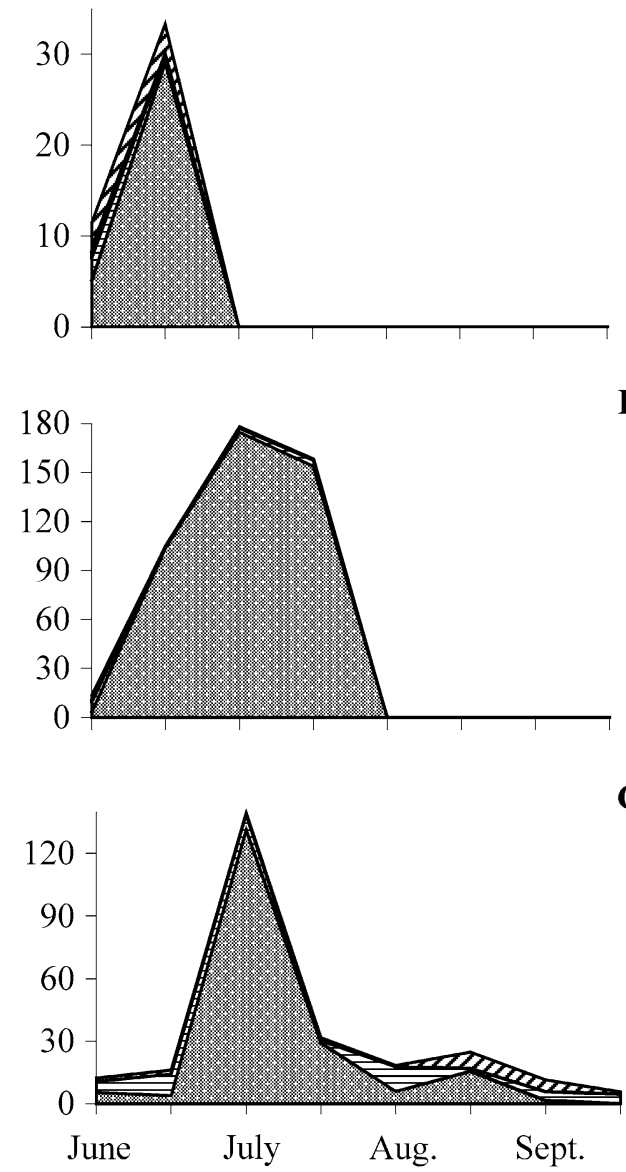
Months
A
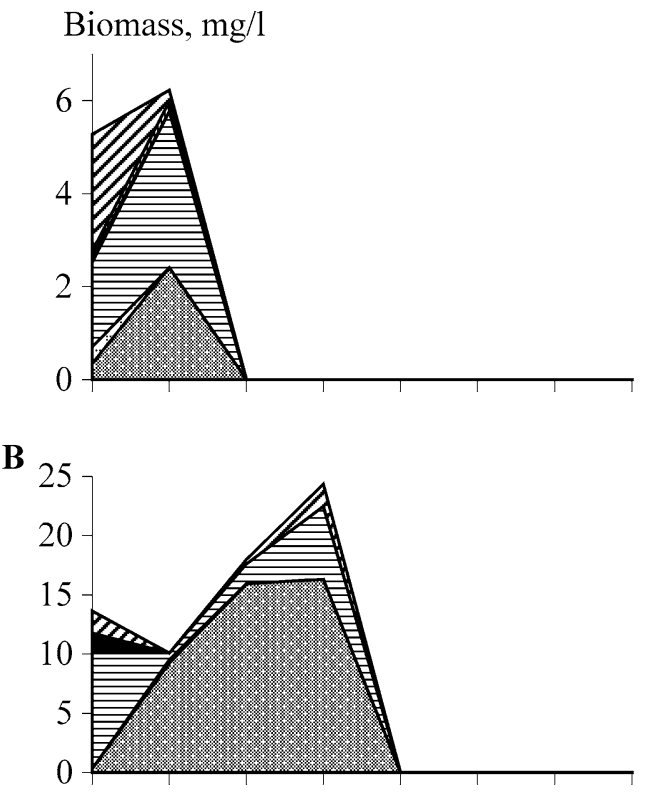

C

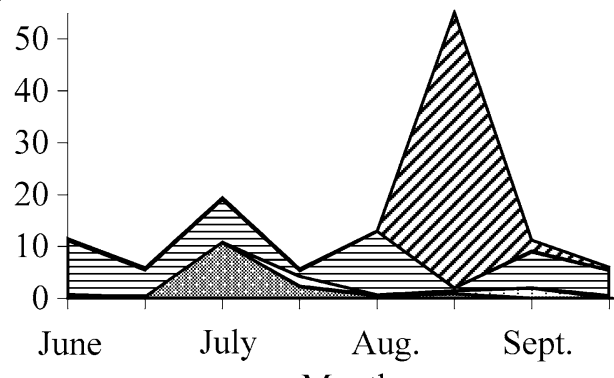

Months
용-1
ㅁㄴ $\square-3$
目 -4
- 5
घ- 6
血 -7
घ-8

Fig. 8 Seasonal dynamics of phytoplankton abundance and biomass in open shallow water at station 1 (a), station 2 (b), and station 3 (c) of site 2 (Saralinsky). Cyanobacteria (1), euglenophytes (2), dinoflagellates (3), diatoms (4), xanthophytes (5), cryptophytes (6), chrysophytes (7), chlorophytes (8)

Cyanobacteria were developing rapidly first in weakly flowing shallow waters which were protected from waves and wind. Then these algae spread to the entire area of the reservoir. Under the meteorological conditions observed during that time period, open shallow water was found to be the most favorable area for cyanobacteria vegetation. At site 2 (Saralinsky) where hydrodynamic activity was intensive, cyanobacteria also occasionally accumulated at the outer edge of the thicket, reaching very high concentrations (up to $4.52 \times 10^{8}$ cells/l). Since the hydrological conditions of the site were not favorable for further development of these algae, such outbreaks in their abundance were short-termed. Due to intensive water dynamics, cyanobacteria could not settle even in the dense thickets of macrophytes.

When the biotopes of site 1 (Pobedilovo) are compared, in this period, no significant differences in quantitative indicators of phytoplankton seasonal changes in the thickets of cats'-tail and reed were observed. High concentration of cyanobacteria was noticed at all stations of this site, with the increase in the thickets closer to the coast. The biomass and abundance of diatoms increased slightly, and the most abundant species were S. hantzschii, Cyclotella meneghiniana Kiitz., Melosira varians Ag., Aulacosira granulata (Ehr.) Sim., A. Italic (Kiitz.) Sim., A. islandica (O. Mull.) Sim., Fragilaria construens (Ehr.) Grun., Nitzschia palea (Kiitz).W.Sm.

With the growth of macrophytes in the thickets, a reduction in the concentration of cyanobacteria and diatoms was detected. In ditch-water, phytoplankton development in the thickets is usually limited by shortage 
of nutrients in water and low lightening. In the dense thickets of reeds and cats'-tail, sometimes less than $1 \%$ of photosynthetically active radiation reaches the surface of the water, resulting in a low number of phytoplankton (Komarkova et al. 1983). In this period, at station 2, the decrease in the total quantity indicators of phyton was also observed. Conversely, the number of euglenophytes Trachelomonas hispida (Perty.) Stein emend. Defl., T. intermedia Dang., Euglena viridis Ehr., Phacus pleuronectes (Ehr.) Daj. and dinoflagellates of the genus Peridinium, i.e. more mobile and mixotrophic forms, increased. The dynamics of algal biomass of these algae groups were the same.

At station 3, in the contact zone of algal communities residing in the thickets and open water, with the development of macrophytes, the abundance and biomass of algae, on the contrary, increased. By the end of July, chlorophytes reached the seasonal peak in abundance, while the numbers of other algae in the water began to decline. The dominant chlorophytes complex consisted of volvocine algae Chlamydomonas sp., Pandorina morum (Mill.) Bory. and Chlorococcales Coelastrum proboscideum Bohl., Crucigenia rectangularis (A.Br.) Gay., C. Tetrapedia (Kirchn.) W.et.W., Oocystis natans Wille., Pediastrum duplex Meyen., Scenedesmus guadricauda (Turp.) Breb. Spatially, the maximal abundance and biomass of chlorophytes were observed at station 3.

At site 2 (Saralinsky), the peaks of quantitative phytoplankton indicators were observed later compared with site 1. In the thickets, the phytoplankton abundance and biomass was 2.5-3 times higher than those in the open shallow water. In all biotopes, the accumulation of cyanobacteria causing "blooming" of water was observed. In open areas more away from the coast (station 3), diatoms, mainly represented by M. varians, Cocconeis placentula Ehr., Cyclotella comta (Ehr.) Kiitz., Gomphonema olivaceum (Lyngb.) Kiitz., A. italica, A. islandica, F. construens, S. hantzschii, Amphora ovalis Kiitz., Tabellaria fenestrata (Lyngb.) Kiitz., Nitzschia palea (Kiitz). W.Sm., Navicula sp. were found in high numbers.

In cats'-tail thickets, closer to the water's edge (stations 1,2), the proportion of diatoms was significantly higher than that of green-blue algae. Also, the number of euglenophytes Euglena viridis Ehr., P. triquetrus (Ehr.) Daj. increased. By the end of July, the concentration of volvocine algae of the genus Chlamydomonas reached $7.5 \times 10^{6}$ cells $/ 1$ and $27.8 \mathrm{mg} / \mathrm{l}$, which accounted for $34.8 \%$ of the total population and $65.8 \%$ of the total phytoplankton biomass. At the same time, the abundance of other algal groups in the thickets started to decrease.

Since July, the water level in the reservoir has been steadily lowering. By the end of September-beginning of October the level was $51 \mathrm{~m}$, which is well below the long-term averages. Due to the lowering of the water level, some shallow water areas were drained in the middle of the summer, and at stations 1 and 2 , only one maximum in biomass occurred. It was possible to follow the dynamics of phytoplankton growth throughout the summer and autumn only at station 3. At the beginning of August, a reduction in the number of all algae groups in the water was detected. The second maximum in phytoplankton abundance and biomass was observed in mid-August due to the intensive development of cyanobacteria and diatoms in the studied biotopes. Main contributors to massive development of cyanobacteria during the summer and autumn period were the species A. flos-aquae, An. flos-aquae, An. scheremetievi, M. aeruginosa. The abundance of M. aeruginosa has increased dramatically in the summer-autumn complex of algae.

The dynamics of the total phytoplankton biomass in the studied biotopes had significant differences. Firstly, in cats'-tail thickets associations, euglenophytes intensively developed at both sites. The same species dominated elsewhere: E. viridis, P. triquetrus, P. pleuronectes, Trachelomonas volvocina Ehr., Trachelomonas hispida (Perty.) Stein emend. Defl. The diatoms of the thickets at site 1 were represented by the species: S. hantzschii, C. comta, C. placentula, A. italica, N. vermicularis, M. varians, F. construens, T. fenestrata, Gomphonema acuminatum Ehr., Nitzschia acicularis W.Sm., Navicula cryptocephala Kiitz., Diatoma elongatum (Lyngb.) Ag.

In the open shallow water of site 2 , diatoms dominated in biomass. The most frequently found species were N. cryptocephala, C. placentula, M. granulata, S. hantzschii, A. ovalis, M. varians, G. olivaceum, Diatoma vulgare Bory., Nitzschia paleacea Grun., Synedra ulna (Nitzsch.) Ehr. The ratio of quantitative indicators of dominant species in the thickets was changing, and the dominant forms (listed in descending order) were $M$. varians, G. acuminatum, G. olivaceum, A. ovalis, C. comta, T. fenestrata, and N. palea.

In the summer-autumn mean-water, the average water level in the reservoir remained at the levels well below the long-term average $(51.0 \mathrm{~m})$ until the middle of November. By the beginning of September, shallow water areas of both sites have dried up below the outer edge of the thickets, and further research continued in 
the shallows below the thickets. During that period, the quantitative indicators of previously dominating algae decreased across the whole reservoir. By the end of water "blooming" caused by cyanobacteria, in all parts of the reservoir, the outbreak of volvocine algae (Carteria multifilis (Fres.) Dill. и Chlamydomonas sp.) abundance occurred and continued in spring 2003 (unpublished observations, Khaliullina).

When volvocine algae abundance started to rise, an increase of biogenic elements in the water was detected (nitrate, ammonium and phosphorus compounds) (Ratushnyak et al. 2006a, b). Aging and death of cyanobacteria (especially M. aeruginosa which biomass was high) cell colonies was coupled with their mineralization. As a result, cellular content was released into water and enriched it with organic compounds. Since then, the water level in the reservoir stayed abnormally low for some time, and the concentration of nutrients in the water remained high. Because of this, fast-reproducing volvocine algae could grow in mass and cause the autumn "blooming" of water. It is known that volvocine algae of the genus Chlamydomonas can develop in large numbers at fairly low temperatures (Vodorosli. lishajniki 1977). Similar cases of water "blooming" causing the development of volvocine algae were described for Cheboksary, Volgograd and Saratov water reservoirs in different years (Gerasimova 1996; Okhapkin 1994).

\section{Conclusion}

Seasonal changes in the total biomass and abundance of phytoplankton in the thickets of macrophytes and in the open areas of the reservoir differed little. During the growing season, two peaks with maximums in JuneJuly and late August were observed at all studied sites.

The development of planktonic algae in the thickets occurs in parallel with the seasonal formation of plant biotopes. In the beginning of summer, when higher aquatic vegetation is developed little, qualitative and quantitative composition of phytoplankton in the thickets and in open water areas differed slightly. With the growth of macrophytes, chlorophytes production is limited by low lightening. In contrast, the content of euglenophytes, dinoflagellates, and diatoms, which are mixotrophic and mobile (i.e. they can find the most favorable location in the water), increases. In mid-summer, the algocoenosis formed in the thickets is different from that residing in the open water areas. This was particularly noticeable during the periods of water mass stability and at the site 1 (Pobedilovo), which is relatively isolated from the pelagic zone of the reservoir and is characterized by more sustained runoff.

In areas of more intense water masses dynamics (site 2, Saralinsky), the effect of macrophyte vegetation on cyanobacteria is less pronounced. Due to wind-driven waves, cyanobacteria occasionally accumulate in high numbers at the outer edge of the thickets. Also, during the periods of sharp increase of the water level, the intensive dynamics of water masses contributes to the widespread distribution of heterotrophic flagellar heterotrophic euglenophytes, dinoflagellates, and cryptomonads, which developed mainly in the thickets of macrophytes.

The zone on the outer edge of the thickets, where an intensive contact with the open water occurs and where the role of true phytoplankton significantly increases, is characterized with the highest species diversity and abundance of algae. For this mixing zone, the "edge effect" is noticed, i.e. there is a tendency for increase in biodiversity and quantitative phytoplankton indicators.

By the end of the summer of 2002, a decrease in water level lower than $51.5 \mathrm{~m}$ led to the autumn outbreak in volvocine algae abundance and biomass, which continued during the spring of the next year (unpublished observations, Khaliullina). Thus, the water level lowering in the reservoir leads to massive development of phytoplankton, cyanobacteria or other algae, representatives of which can be indicators of higher saprobity zones. The maintaining of an optimal water level in the reservoir is recommended for controlling of water "blooming" and thus maintaining high water quality.

Under the conditions of the water reservoir, in the biological communities, all the development processes, having a potential to create a structural and functional order, are regularly interrupted by various factors (flood, rain floods, drought, sedimentation, etc.). Formed communities are also constantly transforming mainly due to water level fluctuations. Therefore, it is impossible to identify clear boundaries of the communities in different biotopes.

Water level fluctuations in the Kuibyshev Reservoir (seasonal or caused by other reasons) primarily affect the shallow coastal waters phytoplankton communities, both in the macrophytes thickets and in the open 
water. Despite the fact that in this work, we found no direct correlations between phytoplankton community structure formation and such factors as concentration of nutrients, relief, dynamics of water masses, and the degree of higher aquatic vegetation overgrowth in the coastal shallow-water littoral zone, apparently these factors together with climatic conditions determine the development of phytoplankton. Lack of pair correlations between algal abundance and abiotic factors is not an indication that the latter ones do not affect the development of phytoplankton. The effects of such factors are often indirect and may appear with delay (Harris 1987; Reynolds 1990). In addition, multiple factors may overlap, which makes it impossible to reveal direct causal connections.

Acknowledgments The studies were done as a part of an international program INTAS: "Metabolic Biodiversity and Monitoring of Benthic forms: Strategies of Adaptation for Different Oxygen regimes controlled with Natural and Anthropogenic factors" in 2002-2004: "Influence of water level fluctuation on Typha-dominated littoral communities of the Kuibyshev Water Reservoir (Tatarstan Republic, Russia)", funded by the Volkswagen Stiftung; Ref. No. I/77 616. The authors are sincerely grateful to Prof. V.A. Yakovlev for the help with the study design and valuable advice throughout the whole study. The work is performed according to the Russian Government Program of Competitive Growth of Kazan Federal University.

Authors' contributions LYu collected and analyzed the water samples and drafted the manuscript. GV helped in analyzing the obtained data and edited the manuscript. All authors read and approved the final manuscript.

\section{Compliance with ethical standards}

Conflict of interest The authors declare that they have no competing interests.

Open Access This article is distributed under the terms of the Creative Commons Attribution 4.0 International License (http:// creativecommons.org/licenses/by/4.0/), which permits unrestricted use, distribution, and reproduction in any medium, provided you give appropriate credit to the original author(s) and the source, provide a link to the Creative Commons license, and indicate if changes were made.

\section{References}

Borovikov VP, Borovikov IP (1998) STATISTICA. statisticheskij analiz i obrabotka dannyh v srede windows [STATISTICA. Statistical analysis and data processing in Windows] (2nd edn). Filin

Gaevskaja NS (1966) Rol' vysshih vodnyh rastenij v pitanii zhivotnyh presnyh vodoemov [The role of higher aquatic plants in animals nutrition in freshwaters]. Nauka

Gerasimova NA (1996) Fitoplankton saratovskogo i volgogradskogo vodokhranilishch [Phytoplankton of the Saratov and Volgograd Reservoirs]. IEVB RAN, Tolyatti

Gidrometeorologicheskii rezhim ozer i vodokhranilishch SSSR. Kuibyshevskoe i Saratovskoe vodokhranilishcha (1978) [Hydrometeorological Regime of Lakes and Reservoirs in the USSR: Kuibyshev and Saratov Reservoirs]. Gidrometeoizdat, Leningrad

Gosudarstvennyj doklad o sostojanii prirodnyh resursov i ob ohrane okruzhajushhej sredy Respubliki Tatarstan v 2002 godu (2003) [National report on the state of natural resources and environmental protection in the Republic of Tatarstan in 2002]. Minprirody RT, Kazan

Gosudarstvennyj doklad o sostojanii prirodnyh resursov i ob ohrane okruzhajushhej sredy Respubliki Tatarstan v 2004 godu (2005) [National report on the state of natural resources and environmental protection in the Republic of Tatarstan in 2004]. Minprirody RT, Kazan

Guseva KA, Jekzercev VI (1966) Formirovanie fitoplanktona i vysshej vodnoj rastitel'nosti v ravninnyh vodohranilishhah [Formation of phytoplankton and higher aquatic vegetation in the plain reservoirs]. In: Jekologija vodnyh organizmov [Ecology of aquatic organisms], Nauka

Harchenko TA (1991) Koncepcija jekotonov v gidrobiologii [The concept of ecotones in Hydrobiology]. Gidrobiologicheskij Zhurnal 27(4):3-9

Harris GP (1987) Phytoplankton ecology: structure, function and fluctuation. Chapman and Hall, New-York, p 384

Hilt S (2006) Allelopathic inhibition of epiphytes by submerged macrophytes. Aquat Bot 85(3):252-256

Kazda M, Yakovlev V, Ivanov D, Gang N, Leffler S, Amenitskij S (2004) The importance of Typha for littoral communities of the Kuybishev water reservoir-overview of the project financed by the Volkswagen foundation. Ecological problems of littoral in flat water reservoirs. International scientific conference, Kazan, pp 45-48

Khaliullina LI (2015) Features of the structural organization of phytoplankton of coastal shallow water of Volga and Volga-Kama reaches of the Kuibyshev Reservoir. Res J Pharm Biol Chem Sci (RJPBCS) 6(4):105-116

Khaliullina LY, Yakovlev V, Khaliullin I (2009) Seasonal and year-to-year dynamics of phytoplankton in connection with the level regime of the Kuibyshev Reservoir. Water Resour 36(4):459-465

Komarkova IJ, Marvan P, Rychkova MA (1983) Pervichnaja produkcija i rol' vodoroslej v litoral'noj zone vodoemov razlichnogo tipa [Primary production and the role of algae in the littoral zone of various types of water bodies]. In: Gidrobiologicheskie processy $\mathrm{v}$ vodoemah [Hydrobiological processes in water reservoirs]. Nauka, Leningrad 
Konovalov SM, Pautova VN (1989) Jekologija fitoplanktona kujbyshevskogo vodohranilishha [Ecology of phytoplankton of the Kuibyshev reservoir]. Nauka, Leningrad

Koreljakova IL (1977) Rastitel'nost' kremenchugskogo vodohranilishha [Vegetation of the Kremenchugskoe Reservoir] Naukova dumka, Kiev

Kujbyshevskoe vodohranilishhe (1983) [The Kuibyshev Reservoir]. Nauka, Leningrad

Kujbyshevskoe vodohranilishhe (2008) [The Kuibyshev reservoir]. IEVB RAN, Tolyatti

Kutova TN (1974a) Rastitel'nost' melkovodij gor'kovskogo vodohranilishha [Vegetation of the shallows of the Gorky Reservoir]. Izvestija GosNIORH 89:30-36

Kutova TN (1974b) Rastitel'nost' mshichinskogo zaliva [Vegetation of the Mshihinskogo Bay]. In: Prirodnye Resursy MologoSheksninskoj Niziny. Rybinskoe Vodohranilishhe [Natural Resources Mologa-Sheksna Lowland. Rybinsk Reservoir], pp 98-110

Lavrent'eva GM (1977) Fitoplankton vodohranilishh volzhskogo kaskada. [Phytoplankton of the Volga cascade reservoirs] Izvestija GosNIORH, 114(6):1937-1938

Morduhaj-Boltovskoj FD (1975) Metodika izuchenija biogeocenozov vnutrennih vodoemov [The methods of studying the biogeocenosis in inland waters], Nauka, Moscow

Mulderij G, Van Nes EH, Van Donk E (2007) Macrophyte-phytoplankton interactions: the relative importance of allelopathy versus other factors. Ecol Model 204(1):85-92

Okhapkin AG (1994) Fitoplankton Cheboksarskogo Vodohranilishha [Phytoplankton in the Cheboksary Reservoir]. IEVB RAN, Tolyatti

Pautova VN, Nomokonova VI (2001) Dinamika fitoplanktona nizhnej volgi-ot reki k kaskadu vodohranilishh [The phytoplankton dynamics in the Lower Volga, from the river to the cascade of reservoirs]. IEVB RAN, Tolyatti

Pautova VN, Nomokonova VI (1994) Produktivnost' fitoplanktona kujbyshevskogo vodohranilishha [Phytoplankton productivity in the Kuibyshev reservoir] IEVB RAN, Tolyatti

Potapov AA (1958) Kormovoe znachenie vodnoj i pribrezhnoj rastitel'nosti vodohranilishh. [Forage value of aquatic and riparian vegetation of water reservoirs] Vestnik Sel'Skohozjajstvennoj Nauki (6):139-144

Qin B, Song Y, Gao G (2006) The role of periphytes in the shift between macrophyte and phytoplankton dominated systems in a shallow, eutrophic lake (lake Taihu, China). Sci China Ser C Life Sci 49(6):597-602

Ratushnyak AA, Borisovich MG, Valeev VS, Ivanov DV, Andreeva MG, Trushin MV (2006a) The hydrochemical and hydrobiological analysis of the condition of the Kuibyshev Reservoir littorals (republic of Tatarstan, Russia). Ekoloji 15(61):22-28

Ratushnyak AA, Borisovich MG, Valeev VS, Ivanov DV, Andreeva MG, Trushin MV (2006b) Diagnostics of the water quality of the Kuibyshev Reservoir littorals with various anthropogenic load: hydrobiological and multifractal analysis. Fresenius Environ Bull 15(7):626-632

Reynolds CS (1990) Temporal scales of variability in pelagic environments and the response of phytoplankton. Freshw Biol 21(1):23-53

Sand-Jensen K, Borum J (1991) Interactions among phytoplankton, periphyton, and macrophytes in temperate freshwaters and estuaries. Aquat Bot 41(1):137-175

Sayer CD, Davidson TA, Jones JI (2010) Seasonal dynamics of macrophytes and phytoplankton in shallow lakes: a eutrophication-driven pathway from plants to plankton? Freshw Biol 55(3):500-513

Schriver P, Bøgestrand J, Jeppesen E, Søndergaard M (1995) Impact of submerged macrophytes on fish-zooplanktonphytoplankton interactions: large-scale enclosure experiments in a shallow eutrophic lake. Freshw Biol 33(2):255-270

Solov'eva VV, Rozenberg GS (2006) Sovremennoe predstavlenie ob jekotonah ili teorija jekotonov [The theory of ecotones]. Uspehi sovremennoj biologii 126(6):531-549

Stepanova NY (1999) Jekologicheskie kriterii normirovanija nagruzki na vodoem v uslovijah ego zagrjaznenija vozvratnymi vodami [Environmental criteria of burden valuation on the pond under the conditions of its pollution with return waters]. Dissertation, Kazan State University

Vodorosli. lishajniki [Algae. Lichens.] (1977) In: Gollerbah AA (ed) Zhizn' rastenij [Plants life]. Prosveshhenie, Moscow

Vodorosli spravochnik (1989) In: Vasser SP (ed) Algae directory. Naukova dumka, Kiev

Zimbalevskaja LN (1972) Raspredelenie fitofil'nyh bespozvonochnyh i metody ih kolichestvennogo ucheta [Distribution of phytophilic invertebrates and the methods for their quantitative count]. Gidrobiologicheski Zhurnal 8(2):49-55

Zimbalevskaja LN (1973) Raspredelenie fitofil'nyh bespozvonochnyh i metody ih kolichestvennogo ucheta [Distribution of phytophilic invertebrates and the methods for their quantitative count]. Gidrobiologicheski Zhurnal 6(9):38-48 